\title{
The Rs4938723 Polymorphism Reduces Expression of MicroRNA-34b and Increases the Risk of Recurrence after Endoscopic Dissection in Early Gastric Cancer
}

\author{
Kuaiyun Yu \\ Department of General Surgery, Yantai mountain hospital of Yantai University, Yantai, China
}

\section{Key Words}

Rs4938723 - MicroRNA-34b • Recurrence - MET • Endoscopic dissection • Early gastric cancer - Apoptosis

\begin{abstract}
Background: In respect to the effect of MET1 upon the recurrence of Early gastric cancer (EGC) after endoscopic dissection (ESD) treatment, we aimed to investigate the molecular mechanism, including the potential regulator and signaling pathways of MET1 in this study. Methods: We searched the miRNA database online (www.mirdb.org) with the "seed sequence" located within the 3'-UTR of the target gene, and then validated MET1 to be the direct gene via luciferase reporter assay system. Real-time PCR and western-blot were used to determine the expression of miR-34b mRNA and MET1 mRNA and protein in different treating group. Results: MET1 was the direct gene of miR-34b by searching the miRNA database online and constructing luciferase reporter. We also investigated the negative regulatory relationship between miR-34b and MET1 via studying the relative luciferase activity at different concentrations of miR-34b mimics. Further, since rs4938723 polymorphism was previously reported to be interfering with the expression of miR-34b, we investigated the expression level of different genotypes including TT $(\mathrm{N}=20), \mathrm{TC}(\mathrm{N}=9)$ and $\mathrm{CC}(\mathrm{N}=3)$, which supported the hypothesis that the presence of minor allele (C) of rs4938723 polymorphism compromised the expression of miR-34b. Meanwhile, we also conducted real time PCR and Western blot analysis to study the mRNA and protein expression level of MET1 among different genotypes or cells treated with different concentration of miR-34b mimics/inhibitors, indicating the negative regulatory relationship between miR-34b and MET1.We also investigated the relative viability of EGC cells when transfected with miR-34b mimics ( $50 \mathrm{nM}$ and $100 \mathrm{nM}$ ) and miR-34b inhibitors (100nM) to validate miR-34b to be negatively interfering with the viability of EGC cells. Conclusion: These data confirmed miR-34b rs4938723 polymorphism was also recognized as a biomarker to predict recurrence after ESD in EGC patients via analysis upon the recurrence-free rate among different genotypes of EGC patients.




\section{Cellular Physiology Cell Physiol Biochem 2017;43:1235-1246

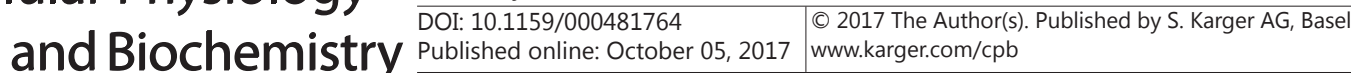

Yu: Rs4938723 Confers to an Increased Risk of Recurrence after ESD

\section{Introduction}

Early gastric cancer (EGC) refers to carcinoma or a lesion which is stricted to the submucosa ormucosa, despite of involvement of lymph node. Good long-term results including 5-year overall survival (OS) rate of $95 \%$ have been obtained by surgical resection (SR) with lymph node dissection which is regarded as a traditional treatment option for EGC, leading to. Nevertheless, contributing to faster recovery, minimal invasiveness,low cost, and improved quality of life after the procedure, endoscopic resection (ER) such as endoscopic submucosal dissection (ESD) and endoscopic mucosal resection (EMR)has been extensively recognized as a standard option for any EGC lesion that is identified as a differentiated intramucosal adenocarcinoma of less than $2 \mathrm{~cm}$ in diameter) without submucosal ulceration and extension [1-3]. ESD allows accurate histopathologicalevaluation of specimens and was designed for the purpose of the en-bloc resection of large mass $[4,5]$. In the endoscopic treatment of gastric cancer at early stage, ESD has present as the better technique than piecemeal EMR when it comes to relapse rates, resulting in overall 5-year relapse-free rates of $100 \%$ versus $82.5 \%$, respectively. Recent studies reported the application of ESD for the treatment of Barrett's neoplasia at early stage and T1 (m) adenocarcinoma at the EGJ [612]. Furthermore, ER become additionally indicated for other lesions at negligible risk for lymph node metastasis (including ulcerated lesions, undifferentiated lesions and larger lesions) contributing to the development of endoscopic technology [13]. An array of recent single-arm studies have focused on the effectiveness of ESD in EGC cases who were eligible for these expanded indications, demonstrating favorable long-term and short-term clinical results [14].This method, however, sometimes has a few of major drawbacks such as high incidence of metachronous gastric cancer regardless of its effectiveness [15]. Furthermore, the long-term clinical effectiveness of ER versus SR in EGC patients remains largely unknown [16].

As single-stranded RNA molecules consisted of 19 21 nucleotides, miRNAs are associated with the expression of posttranscriptional gene and mRNA cleavage or translational suppression by binding to ideally complementary mRNA sequences to damagethe target transcript [17]. The original clone of mir-34 family including miR-34a, miR-34b and miR$34 \mathrm{c}$ dated back to 2007 and they were regarded as tumor inhibitors [18]. miR-34c and miR-34b are encoded by a common primary transcript termed as pri-miR-34b while the miR-34a is transcribed separately [19]. Moreover, microarray analysis demonstrated that the miR-34 family could inhibit a set of genes, which were pivotal in the development of tumor, as CDK4/6, MET, Bcl-2 and so on [19]. Studies have reported the association between several cancer risk and rs4938723 ( $\mathrm{T}>\mathrm{C}$ ), which is located in the promoter region of pri-miR$34 \mathrm{~b}$ and defined as a single nucleotide polymorphism in the CpG island [20]. According to reports, it had effect on the binding of transcription factor GATA and further the expression of pri-miR-34b [21].

Rs4938723 situated in the precursor of miR-481 has been shown to undermine the expression of the miRNA, leading to a decreased expression level of miR-481 [22, 23]. Meanwhile, MET is thought to play an important role in the pathogenesis of the recurrence after ESD, and we also identified MET as a virtual target of miR-481 by using in-silicon analysis. In the present study, we verified the regulation of MET by miR-481 and identified the role of rs4938723 polymorphism in the development of the recurrence after ESD [2426].

\section{Materials and Methods}

Sample collection

A total of 502 were recruited at the Department of General Surgery, Yantai mountain hospital of Yantai University (Yantai, china) between Jun 2013 and Nov in 2014. All the participants was diagnosed with early 


\section{Cellular Physiology Cell Physiol Biochem 2017;43:1235-1246 \begin{tabular}{l|l|l|} 
and BOI: 10.1159/000481764 & $\begin{array}{l}\text { C } 2017 \text { The Author(s). Published by S. Karger AG, Basel } \\
\text { www.karger.com/cpb }\end{array}$
\end{tabular}}

Yu: Rs4938723 Confers to an Increased Risk of Recurrence after ESD

gastric cancer, and underwent a surgery of endoscopic dissection (ESD) prior to our research. All participant donated $5 \mathrm{ml}$ of peripheral blood after being fully informed about the details of the study. Gastric samples were collected from 45 patients for the functional analysis. The research process was in conformity with the last vision of Declaration of Helsinki., and the protocol of the study was approved by the Ethics Committee of Yantai University, All participants have already signed the informed consent after carefully explained before their inclusion in the study.

Genotyping by taqman genotyping kit

Qiagen Genomic DNA extraction kits (Valencia, CA, USA) were used to extract DNA from GC9811 cells according to protocol. Pfu Turbo DNA polymerase (Stratagene, CA, USA) was used to amplified cDNA (MET) with carefully designed primers, an allelic discrimination assay was used to assess the genotyping for the MET SNP (rs4938723).

RNA isolation and real-time PCR

TRIzol reagent (Invitrogen, California, USA) was used to extract the total RNA from tissue samples and GC9811 cells according to the manufacturer's protocol. M-MLV Reverse Transcriptase (Promega, Madison, WI, USA) was used to perform the reverse transcribed, the ABI 7500 fast sequence detection system (Applied Biosystems, Foster, USA) containing a SYBR green fluorescent label was used to perform the realtime PCR with a mixture of $0.25 \mu \mathrm{L}$ of the RT reaction, $1 \mu \mathrm{L}$ of Power SYBR Green PCR Master Mix (Applied Biosystems, Foster, USA) and 3-5 pmol of each primer in optically clear 96-well plates (Corning, NY). The parameters of the thermo were carried out for $10 \mathrm{~min}$ at $95^{\circ} \mathrm{C}, 15 \mathrm{~s}$ at $95^{\circ} \mathrm{Cfor} 40$ cycles, $60 \mathrm{~s}$ at $60^{\circ} \mathrm{Cand}$ an $30 \mathrm{~s}$ at $72^{\circ} \mathrm{Cfor}$ extension/detection. The expression of MET mRNA and miR-481 was calculated relative to expression level of endogenous control $\beta$-actin. $2^{-\Delta \Delta \mathrm{Ct}}$ method described elsewhere was used to analyze the relative quantification of CNACAC1 mRNA and miR-481. All tests were repeated in triplicate.

\section{Cell culture and transfection}

Dulbecco's modified Eagle's medium (DMEM, Invitrogen, California, USA) containing the $100 \mu \mathrm{g} / \mathrm{mL}$ streptomycin, $100 \mathrm{U} / \mathrm{mL}$ penicillin and $20 \%$ FCS (foetal calf serum) was used to incubate the GC9811 cells at $37^{\circ} \mathrm{C}$ with $5 \% \mathrm{CO}_{2} / 95 \%$ air as described previously. Lipofectamine 2000 (Invitrogen, Carlsbad, CA, USA) was used to perform the transfection according to the manufacturer's protocol. The $2.5 \times 10^{6}$ GC9811 cells transfect with the siRNA against MET (siMET), miR-481 mimics, inhibitors and $1 \mu \mathrm{M}$ pooled non-targeting siRNA (siCtrl) as described before. Three independent experiments were performed.

\section{Cell proliferation assay}

3-(4, 5-dimethylthiazole-2-yl)-2, 5-diphenyl tetrazolium bromide assay was used to perform the cell proliferation assay as described previously. GC9811 cells were incubate into 96 wells plate for 1, 2, 3, 4 or 5 days, and $20 \mu \mathrm{L}$ MTT (3-(4, 5-dimethylthiazole-2-yl)-2,5-diphenyl tetrazolium bromide) $(0.5 \mathrm{mg} / \mathrm{mL})$ was added into each well, and maintained for 3 hours, acidic isopropanol with $0.04-0.1 \mu \mathrm{M} \mathrm{HCl}$ was used to solubilize the GC9811 cells which was converted dye (formazan). Finally the cell proliferation assay was measured based on the absorbance at $590 \mathrm{~nm}$. All experiments were repeated in triplicate.

\section{Luciferase assay}

The 3'-UTR (untranslated region) of MET with the binding site of miR-481 was amplified through PCR as described before, and the PCR product was inserted into the SacI/Xbal site of pmirGLO Dual-Luciferase miRNA Target Expression Vector (Promega, Madison, WI, USA), and the fragment of MET-3'-UTR mutant which was constructed by mutating the seed region of the miR-481 binding site was also inserted into the same sites at the same times. The FuGENERHD transfection reagent (Promega, Madison, WI, USA) was used to cotransfect the GC9811 cells with $25 \mathrm{nM}$ miR-481 mimics, $25 \mathrm{nM}$ RNA mimics (negative control) (Gene Pharma, Shanghai, China) and 150 ng pmirGLO-MET-3'-UTR plasmid or pmirGLO-mut CAACNC1-3'UTR plasmid. The Dual-GloRLuciferase Assay System (Promega, Madison,WI, USA) was used to analyze the luciferase activity 24 hours after transfection, Renilla luciferase activity /firefly luciferase activity was used as control. GLoMaxR20/20 (Promega,Madison, WI, USA) was used to analyze the luciferase activity according to manufacturer's protocol. Each test was run in triplicate. 


\section{Cellular Physiology Cell Physiol Biochem 2017;43:1235-1246 \begin{tabular}{l|l|l} 
and Biochemistry Published online: October 05, 2017 & $\begin{array}{l}\text { (c) } 2017 \text { The Author(s). Published by S. Karger AG, Basel } \\
\text { www.karger.com/cpb }\end{array}$
\end{tabular}}

\section{Western blot analysis}

After all treatment, the GC9811 cells were harvested, and ice-cold PBS (phosphate-buffered saline) was used to wash the GC9811 cells and tissue samples twice. And the RIPAII (Invitrogen, California, USA) containing complete protease inhibitor mix, $0.1 \%$ sodium dodecyl sulfate, $0.5 \%$ Na-DOC, $1 \%$ NP-40, $0.05 \%$ NaN3, $50 \mathrm{mM}$ Tris (pH 7.4) and $500 \mathrm{mM} \mathrm{NaCl}$ was used to lyse the cells for half an hour, and the celluar lysates were centrifuged for 15 minutes at $15000 \mathrm{rpm}$ at $4^{\circ} \mathrm{C}$ to get the supernatants (total cell lysates). BCA quantification (Pierce, Thermo Fisher Scientific, Massachusetts, USA) was used to measure the equal amounts of protein. 12\% SDS-PAGE (poly-acrylamide gel electrophoresis) was used to separate the protein, and the iBlot system (Invitrogen, California, USA)was used to transfer the protein to an Immobilon-P membrane (Millipore, Bedford, MA) for 2 hours (120 V). The primary antibodies mouse anti-MET (1:5000, Calbiochem, Merck, Darmstadt, Germany) and anti- $\beta$-actin (1:8000, Calbiochem, Merck, Darmstadt, Germany) was used to treat the membrane at $4^{\circ} \mathrm{C}$ overnight, and then the secondary anti-rabbit antibodies conjugated to horseradish peroxidase (HRP) at 1:10000 dilution (Dako, Danish) were used to treat the membrane for another 2 hours. SuperSignal West Dura chemiluminescent kit (Pierce, Thermo Fisher Scientific, Massachusetts, USA) was used to detect the expreesion of MET protein exposed on X-ray film (Fuji, Tokyo, Japan). Three independent tests were performed.

\section{Statistical analysis}

SPSS 10.0 statistical software for Windows (SPSS, IBM, Chicago, US) was used to performed the Statistical analyses as described before. The value of P less than 0.05 was considered statistically significant. Kaplan-Meier method was used to perform the univariate survival analysis, and the log-rank test was used to assess the survival differences between the groups, predictors related to survival was performed using the Cox proportional hazards model for multivariate survival analysis. Logistic regression analysis was used to determine the SNP of the genotyping.

\section{Results}

\section{MET1 was a target of miR-34b}

MET1 has been previously reported has a crucial role in maintenance of CG methylation, the expression level of which would affect the recurrence of EGC after ESD treatment. In this study, we aimed to investigate the molecular mechanism, including the potential regulator and signaling pathways of MET1, which underlies the recurrence of EGC after ESD treatment. As shown in Fig. 1, we identified miR-34b as a potential regulator of MET1 by searching the miRNA database online (www.mirdb.org) with the "seed sequence" located within the 3'UTR of the target gene.

Furthermore, to validate the regulatory relationship between miR-34b and MET1, we also conducted luciferase activity reporter assay in gastric cancer cells co-transfected with wild-type MET1 3'UTR constructs with different concentration of miR-34b mimics (25nM, 50nM and 100nM) and mutant-type MET1 3'UTR with miR-34b mimics (25nM, 50nM and $100 \mathrm{nM}$, and only $100 \mathrm{nM}$ presented). As shown in Fig. 2, the relative luciferase activity of cells transfected with wild-type MET1 3'UTR constructs evidently down-regulated as the concentration of miR-34b mimics increased compared with the scramble control $(\mathrm{P}<0.05)$, exhibiting a negative regulation in a stepwise manner. On the contrary, cells carrying mutant MET1 3'UTR constructs up-regulated the comparable relative luciferase activity index when

Fig. 1. MET1 was identified as the candidate target gene of miR-34b in gastric cancer cells with the 'seed sequence' in the 3'UTR of MET1 by searching the miRNA database online (www.mirdb. org).

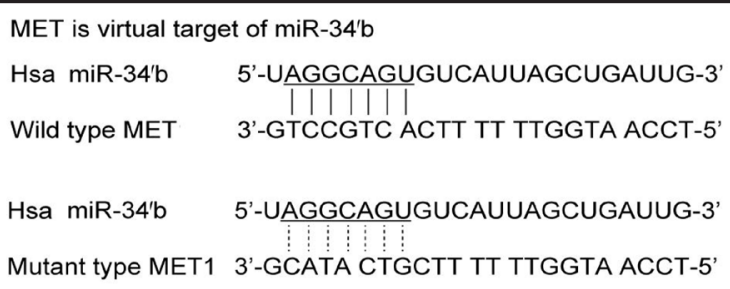




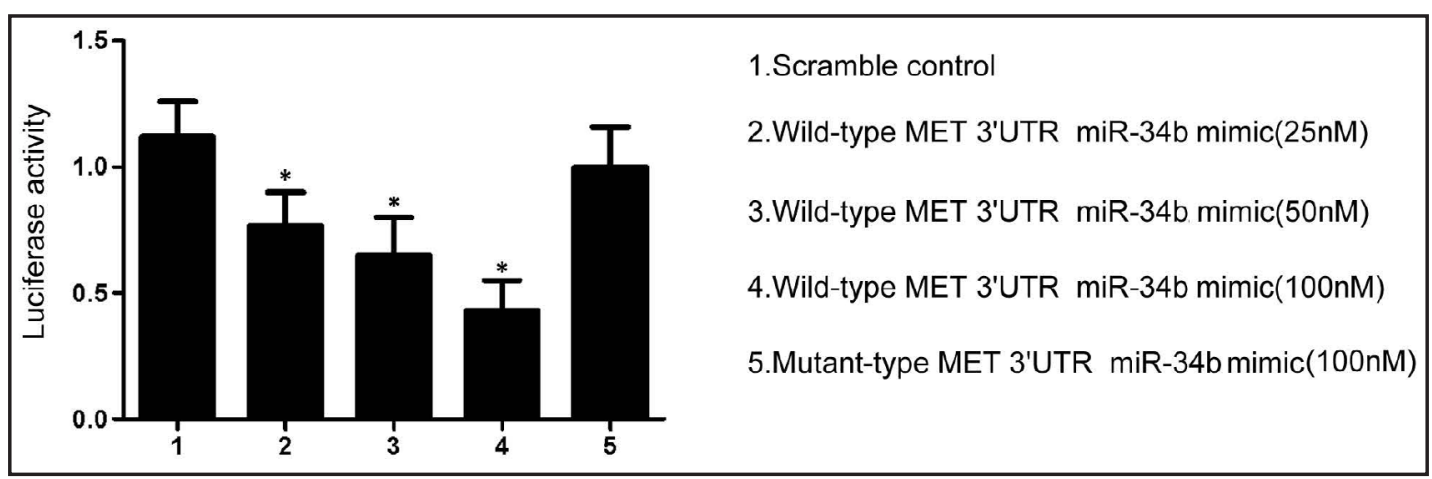

Fig. 2. Luciferase activity reporter assay was conducted to verify MET1 as the direct target gene of miR-34b as well as to validate the regulatory relationship between miR-34b and MET1, gastric cancer cells co-transfected with wild-type MET1 3'UTR constructs with different concentration of miR-34b mimics (25nM, 50nM and $100 \mathrm{nM}$ ) and mutant-type MET1 3'UTR (25nM, 50nM and 100nM, and only $100 \mathrm{nM}$ presented). Compared with the scramble control, the relative luciferase activity of cells transfected with wild-type MET1 3'UTR constructs evidently decreased as the concentration of miR-34b mimics increased, exhibiting a negative regulation in a stepwise manner. On the contrary, cells carrying mutant MET1 3'UTR constructs exhibited comparable relative luciferase activity index when compared with the scramble controls, indicating MET1 as the direct target gene of miR-34b with the binding site located at the segment which has been mutated.

Fig. 3. PCR (qRT-PCR) was performed to confirm rs4938723 polymorphism affected expression of miR-34b in EGC with early recurrence after ESD in different genotype groups. The expression of miR$34 \mathrm{~b}$ in cells carried CC $(\mathrm{N}=26)$ genotype was much higher compared with TT $(\mathrm{N}=6)$ and TC $(\mathrm{N}=13)$, and expression of miR-34b in cells carried TC $(\mathrm{N}=13)$ genotype was up-regulated than TT $(\mathrm{N}=6)$ group.

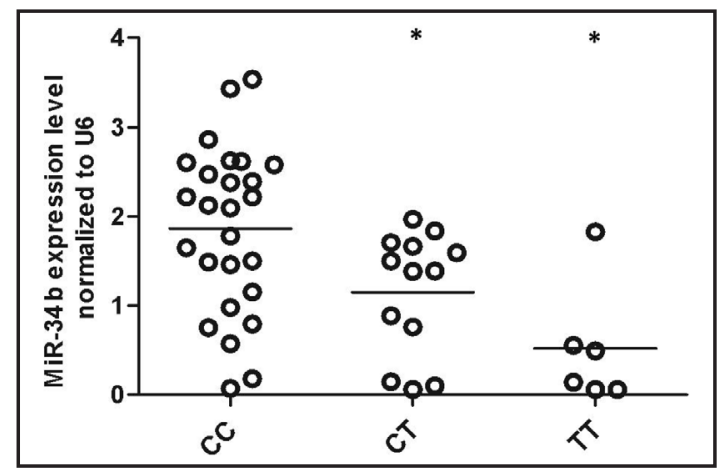

compared with the scramble controls $(\mathrm{P}<0.05)$, suggesting MET1 as the direct target gene of miR-34b with the binding site located at 3'-UTR of the target gene which has been mutated.

Expression level of miR-34b and MET1 varied in different genotype groups of rs4938723 polymorphism

To confirm rs4938723 polymorphism affected expression of miR-34b in EGC with early recurrence after ESD in different genotype groups, we evaluated the expression of miR-34b in 50 recurrence positive and recurrence negative frozen EGC tissues using quantitative reverse transcriptase PCR (qRT-PCR). As shown in Fig. 3, the expression of miR-34b in cells carried CC $(\mathrm{N}=26)$ genotype was much higher compared with TT $(\mathrm{N}=6)$ and $\mathrm{TC}(\mathrm{N}=13)$ $(\mathrm{P}<0.05)$, and expression of miR-34b in cells carried TC $(\mathrm{N}=13)$ genotype was up-regulated than TT $(\mathrm{N}=6)$ group $(\mathrm{P}<0.05)$, suggesting the presence of minor allele $(\mathrm{C})$ of rs4938723 polymorphism compromised the expression of miR-34b.

Western blot analysis and real time PCR were used to study the mRNA and protein expression level of MET1 among different genotypes. As shown in Fig. 4, both the mRNA and protein expression level of MET1 of the TT sample group were evidently higher when compared with the minor allele carrying groups, TC and CC sample groups $(\mathrm{P}<0.05)$, indicating the negative regulatory relationship between miR-34b and MET1. 


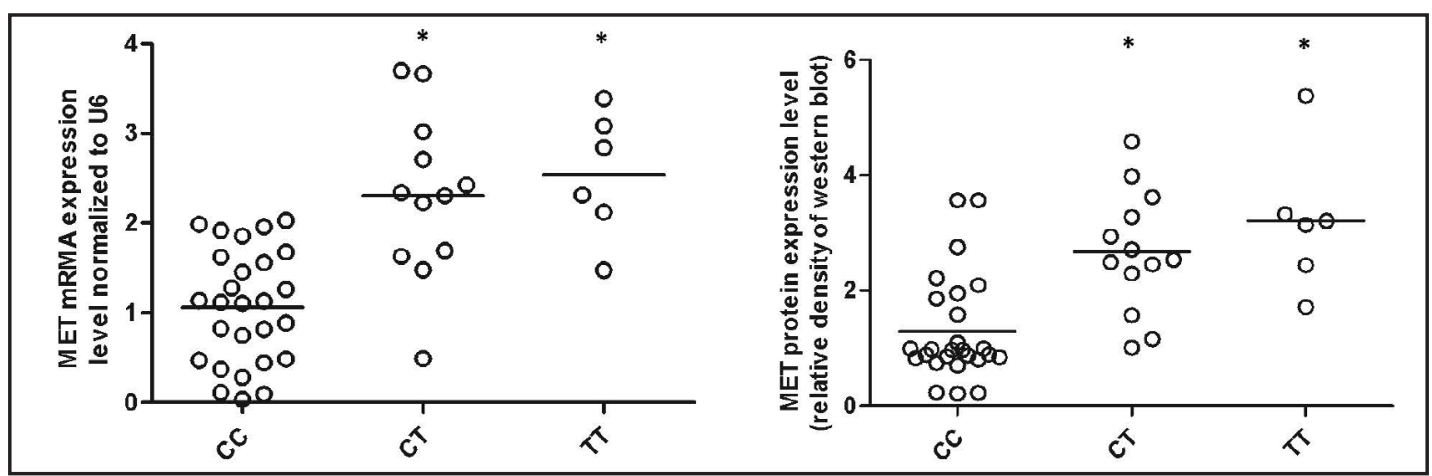

Fig. 4. Real time PCR and Western blot analysis were conducted to study the mRNA and protein expression level of MET1 among different genotypes. The mRNA (left panel) and protein (right panel) expression level of MET1 of the CC sample group were evidently lower when compared with the minor allele carrying groups, TC and TT sample groups.

Fig. 5. RT-PCR was used to further confirm the miRNA-mRNA regulatory relationship. According to the results, confirmed the negative regulatory relationship between miR-34b and MET1, and the negative correlation coefficient was -0.4087 .

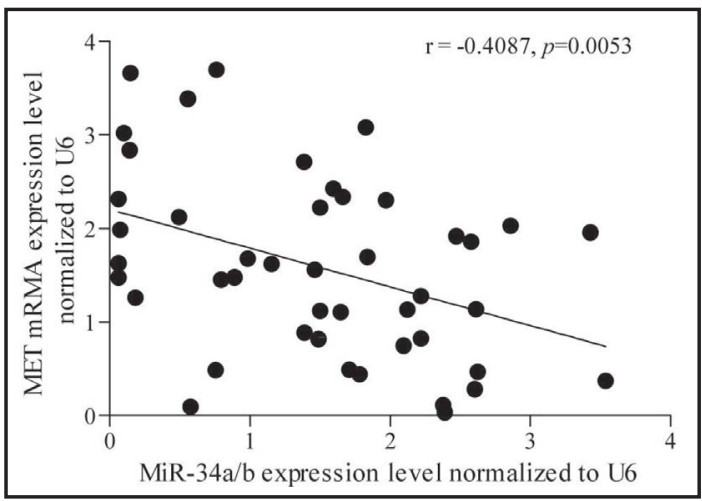

Fig. 6. We investigated the mRNA/protein expression level of MET1 of EGC cells treated with $50 \mathrm{nM}$ miR-34b mimics, $100 \mathrm{nM}$ miR-34b mimics and 100nM miR-34b inhibitors to validate the negative regulatory relationship between miR-34b and MET1, A: The MET1 protein (upper panel) of EGC cells treated with $50 \mathrm{nM}$ miR-34b mimics were apparently lower than the scramble control, while those of the sample group treated with $100 \mathrm{nM}$ miR-34b mimics were even lower than the 50nM treatment group, B: The miR-34b inhibitors treatment group showed evidently higher expression level of mRNA (lower panel) when compared with the scramble controls and the miR$34 \mathrm{~b}$ mimics treatment groups.

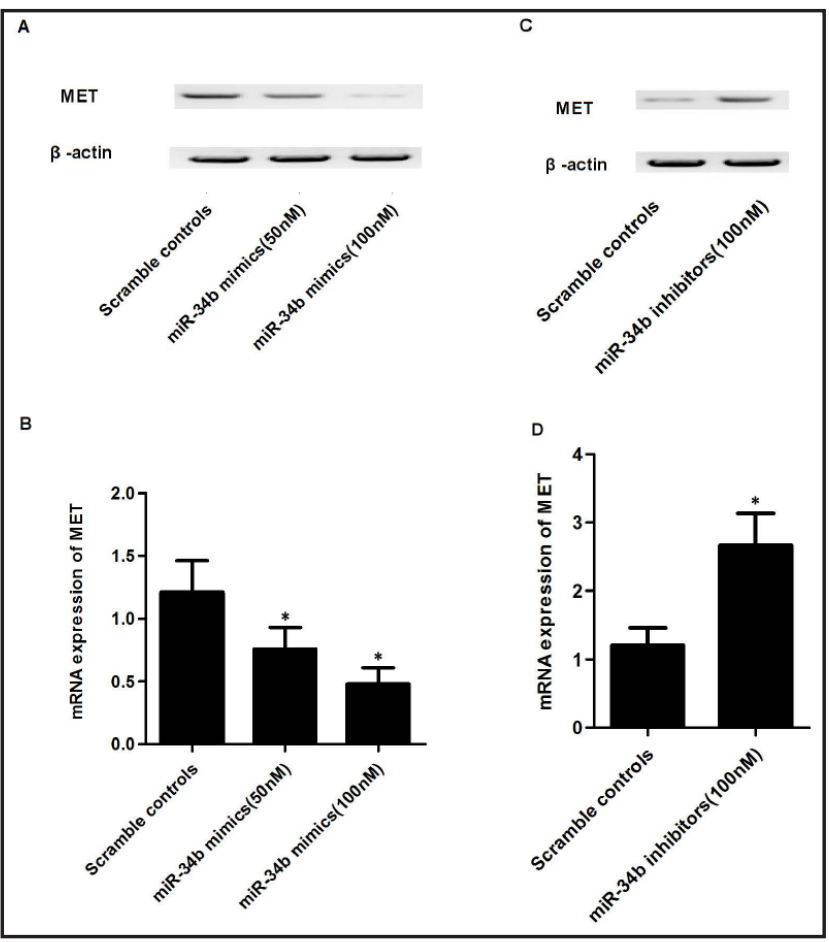

Identification the negative regulatory relationship between MET1 and miR-34b

To further confirm the miRNA-mRNA regulatory relationship, RT-PCR was used to examine the expression level of MET mRNA and the expression of miR-34b. According 
to the results, confirmed the negative regulatory relationship between miR-34b and MET1with the negative correlation coefficient being - 0.4087 , as shown in Fig. 5.

MiR-34b inhibits the expression of MET1

To further validate the hypothesis of the negative regulatory relationship between miR-34b and MET1, we investigated the mRNA/protein expression level of MET1 of EGC cells treated with $50 \mathrm{nM} \mathrm{miR-34b} \mathrm{mimics,}$ $100 \mathrm{nM}$ miR-34b mimics and $100 \mathrm{nM}$ miR$34 \mathrm{~b}$ inhibitors. As shown in Fig. 6, the MET1 protein (upper panel) and mRNA expression level (lower panel) of EGC cells treated with 50nM miR-34b mimics were apparently lower than the scramble control $(\mathrm{P}<0.05)$, while those of the sample group treated with $100 \mathrm{nM}$ miR-34b mimics were even lower than the $50 \mathrm{nM}$ treatment group $(\mathrm{P}<0.05)$, indicating a concentration-dependent effect of miR-34b on the expression of MET1. Meanwhile, the miR-34b inhibitors treatment group showed remarkably higher expression level of MET1 protein (upper panel) and mRNA (lower panel) when compared with the scramble controls and the miR-34b mimics treatment groups $(\mathrm{P}<0.05)$, validating the negative regulatory relationship between miR-34b and MET1.

MiR-34b interfered with the viability of EGC cells

MTT assay was used to perform the analysis of cell viability, we also investigated the relative viability of EGC cells when transfected with miR-34b mimics (50nM and $100 \mathrm{nM}$ ) and miR-34b inhibitors (100nM). As shown in Fig. 7, the viability of cells transfected with $100 \mathrm{nM}$ miR-34b inhibitors showed evidently higher when compared with the scramble controls $(\mathrm{P}<0.05)$, while the viability of cells transfected with 50nM/100nM miR-34b mimics showed comparably lower $(\mathrm{P}<0.05)$, indicating miR$34 \mathrm{~b}$ negatively interfered with the viability of

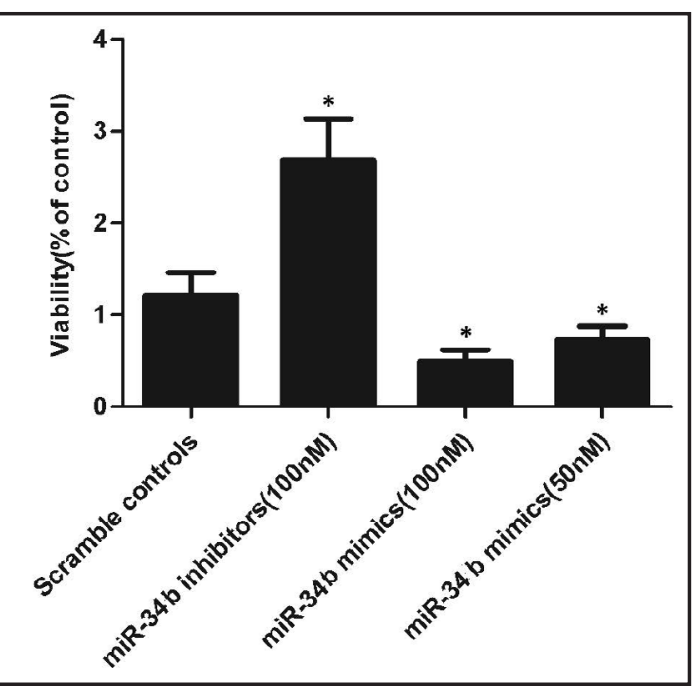

Fig. 7. MTT assay was used to perform the analysis of the effect of miR-34b on cell viability, the viability of cells transfected with $100 \mathrm{nM}$ miR-34b inhibitors showed evidently higher when compared with the scramble controls, while the viability of cells transfected with $50 \mathrm{nM} / 100 \mathrm{nM}$ miR-34b mimics showed comparably lower.

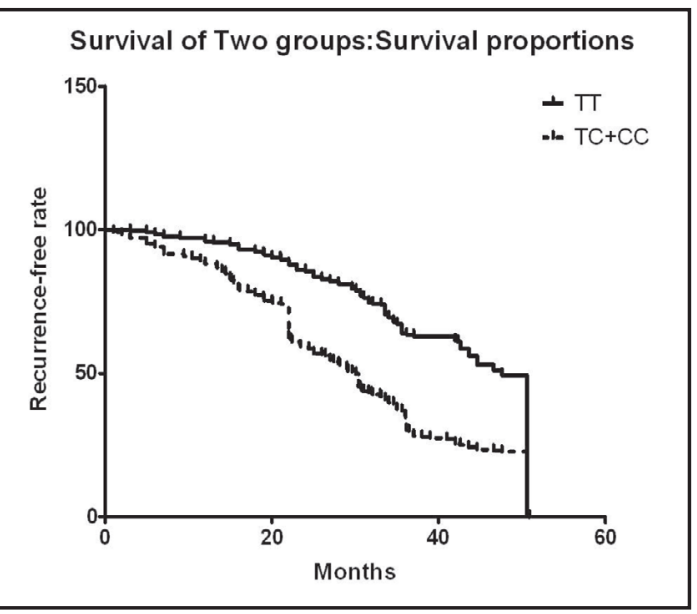

Fig. 8. Cox proportional hazard model analysis was used to observe the time period between the ESD treatment and the recurrence. The recurrence-free rate was significantly longer in TT than TC/CC individuals among the 100 EGC patients enrolled. EGC cells.

\section{MiR-34b rs4938723 polymorphism as a biomarker to predict recurrence after ESD in EGC} patients

To study the association between rs4938723 located in miR-34b polymorphism and risk of recurrence in EGC patients who received ESD treatment, we enrolled 100 EGC patients to observe the time period between the ESD treatment and the recurrence using 


\section{Cellular Physiology Cell Physiol Biochem 2017;43:1235-1246

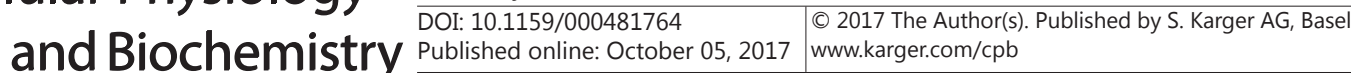

Yu: Rs4938723 Confers to an Increased Risk of Recurrence after ESD

Cox proportional hazard model analysis. As shown in Fig. 8, when the recurrence rate was analyzed via the log rank test, the recurrence-free rate was significantly longer in TT than TC/CC individuals $(\mathrm{P}<0.05)$, indicating miR-34b rs4938723 polymorphism could functions as a biomarker to predict recurrence after ESD in EGC patient.

\section{Discussion}

The incidence of early gastric cancers tends to be on the rise, and for a a lot patients who have early gastric cancer stomach cancer can be cured contributing to improvement in techniques for diagnostic surveillance [27]. Additionally, practically negligible positive rate of metastasis to lymph node has been observed in intramucosal gastric carcinomas (IGCs). Therefore, IGCs account for the majority of candidates appropriate for minimally invasive surgical procedures like endoscopic submucosal dissection (ESD). However, relapses and metastasis to regional lymph nodes and even to liver do occur in some intramucosal carcinomas which may [26].

The main candidate for endoscopic treatment is early gastric cancer, particularly differentiated intramucosal carcinoma which is at a particularly low risk of metastasis to lymph node. Actually, that doesn't mean these tumors are in the safety zone [28]. The metastasis indeed occurs although the incidence of such cases is extremely low. As a protooncogen, MET encodes the receptor tyrosine kinase for hepatocyte growth factor (HGF). Regulated expression of MET has an effect in normal physiologic processes including wound healing and organ regeneration, and an increasing evidences demonstrate that cancers with augmented MET activity promote cell growth, prevention from apoptosis, and invasion and metastasis $[29,30]$. Several studies demonstrate that a variety of biological functions including cell proliferation, survival, invasion and tumor metastasis are mediated by the activation of MET signaling pathway [30]. The activation of MET is associated with oncogenesis in a variety ofhuman cancers [31]. It is critical in the occurrence and progression of primary tumors and metastasis [32]. High MET expressions have been associated with the metastatic dissemination of tumors and unfavorable prognosis in cases with a diversity of solid tumors $[33,34]$. Studies have observed the activation of MET signaling in some non small cell lung cancer (NSCLC) tumors which harbor mutations that activate EGFR [35, 36]. Furthermore, adoptive resistance to EGFR tyrosine kinase (TK) suppressants in NSCLC has been correlated with focal amplification of the MET proto-oncogene [37].

It was turned out that MicroRNA-34(miR-34)- an evolutionarily conserved miRNA family which include miR-34a, b and c forms-is a target of p53 gene encoding a transcriptional factorwhich is associated with apoptosis pathways and growth inhibition. Abnormal expression of miR-34a and miR-34b was found to mediate a cell-cycle arrest in theG1 phase [38]. Additionally, cell proliferation and colony formation in soft agar could be inhibited by miR-34b [39]. Moreover, higher levels of miR-34a and miR-34b in human fibroblasts could result in cellular senescence [38]. In addition, in a variety of cancer with mutation of p53 tumor suppressor gene, low expression of miR-34a and miR-34b was found [40]. It is interesting that ectopic miR-34b could impact the expression of hundreds of putative target genes that are implicated in control of cell cycle and DNA damage responses including Cyclin E2, CDK4/6and Bcl-2 $[19,38]$. In this study, we searched the miRNA database online (www.mirdb.org) with the "seed sequence" located within the 3'-UTR of the target gene, and then validated MET1 to be the direct gene via luciferase reporter assay system. We also established the negative regulatory relationship between miR-34b and MET1 via studying the relative luciferase activity at different concentrations of miR-34b mimics [41].

The effect of miRNA single nucleotide polymorphisms (SNP) in medical conditions is just being identified. For instance, SNPs in miRNAs in cancer have been determined; mir$125 \mathrm{a}$, foundto be changedin breast cancer, exhibitsa variant allele at one SNP ofthe mature miRNA sequence that causes decrease dexpression [42, 43].The members of miR-34 family have been defined as direct transcriptional targets of the tumor inhibitorp53 [44]. p53 - 
also known as the guardian of the genome-has pivotal effect in the tumor prevention and development by regulating miR-34. miR-34 plays a regulatory effect in cell cycle progression and apoptosis by binding to the 3'- untranslated region of target genes which affect their expression. Recently, it was predicted that the promoter region of pri-miR-34b (i.e., rs4938723T/C) has a potentially functional variant that impacts the GATA-X binding sites, and the polymorphism was shown to promote the sensitivity to HCC [21]. However, our currentresults suggested that miR-34b rs4938723 plays a role in prevention from gastric cancer. Several factorsmay be associated with the contradictory findings in HCC and gastric cancer. One of them is that the same polymorphism can have different effects depending on the types of cancer. In addition, the methylation of miR-34b in HCC has not been identified currently, while CpG methylation of miR-34b has been determined in a variety of human cancers such as colorectal carcinoma and gastric cancer $[45,46]$. Moreover, contradictory results may be caused by differences in the levels of methylation between HCC and gastric cancer. More studies including one conducted in a large population are necessary to verify our observations [47]. Actually, many miRNAs including miR-34b have been reported to be involved in the pathogenesis of the development of gastric cancer, and MET, as one of the target gene of miR-34b, has also been reported to be play a role in the oncogenesis of the gastric cancer [48-51]. In this study, we conducted real time PCR and Western blot analysis to study the mRNA and protein expression level of MET1 among different groups (TT, TC, $\mathrm{CC}$ ) or cells treated with different concentration of miR-34b mimics/inhibitors, we found the expression of miR-34b in cells carried CC $(\mathrm{N}=26)$ genotype was much higher compared with TT $(\mathrm{N}=6)$ and TC $(\mathrm{N}=13)$, and both the mRNA and protein expression level of MET1 of the TT sample group were evidently higher when compared with the minor allele carrying groups, TC and CC sample groups. And the MET1 protein/mRNA expression level of EGC cells treated with 50nM miR-34b mimics were apparently lower, while those of the sample group treated with $100 \mathrm{nM}$ miR-34b mimics were even lower, and the miR-34b inhibitors treatment group showed remarkably higher expression level of MET1 protein /mRNA when compared with the scramble controls and the miR-34b mimics treatment groups.

Furthermore, we also investigated the relative viability of EGC cells when transfected with miR-34b mimics (50nM and $100 \mathrm{nM})$ and miR-34b inhibitors $(100 \mathrm{nM})$ to validate miR-34b to be negatively interfering with the viability of EGC cells. And miR-34b was also recognized as a potential biomarker to predict recurrence after ESD in EGC patients via analysis upon the recurrence-free rate among different groups of EGC patients.

\section{Conclusion}

These data confirmed miR-34b rs4938723 polymorphism was also recognized as a biomarker to predict recurrence after ESD in EGC patients via analysis upon the recurrencefree rate among different genotypes of EGC patients.

\section{Disclosure Statement}

None.

\section{References}

1 Kim YW, Yoon HM, Yun YH, Nam BH, Eom BW, Baik YH, Lee SE, Lee Y, Kim YA, Park JY, Ryu KW: Long-term outcomes of laparoscopy-assisted distal gastrectomy for early gastric cancer: result of a randomized controlled trial (COACT 0301). Surg Endosc 2013;27:4267-4276. 


\section{Cellular Physiology Cell Physiol Biochem 2017;43:1235-1246 and Biochemistry \begin{tabular}{l|l} 
DOI: 10.1159/000481764 \\
Published online: October 05, 2017 & $\begin{array}{l}\text { O } 2017 \text { The Author(s). Published by S. Karger AG, Basel } \\
\text { www.karger.com/cpb }\end{array}$ \\
\cline { 2 - 3 }
\end{tabular}

Yu: Rs4938723 Confers to an Increased Risk of Recurrence after ESD

2 Isomoto H, Shikuwa S, Yamaguchi N, Fukuda E, Ikeda K, Nishiyama H, Ohnita K, Mizuta Y, Shiozawa J, Kohno S: Endoscopic submucosal dissection for early gastric cancer: a large-scale feasibility study. Gut 2009;58:331-336.

-3 Japanese Gastric Cancer A: Japanese gastric cancer treatment guidelines 2010 (ver. 3). Gastric Cancer 2011;14:113-123.

-4 Gotoda T, Kondo H, Ono H, Saito Y, Yamaguchi H, Saito D, Yokota T: A new endoscopic mucosal resection procedure using an insulation-tipped electrosurgical knife for rectal flat lesions: report of two cases. Gastrointest Endosc 1999;50:560-563.

-5 Saito Y, Uraoka T, Matsuda T, Emura F, Ikehara H, Mashimo Y, Kikuchi T, Fu KI, Sano Y, Saito D: Endoscopic treatment of large superficial colorectal tumors: a case series of 200 endoscopic submucosal dissections (with video). Gastrointest Endosc 2007;66:966-973.

6 Nakamoto S, Sakai Y, Kasanuki J, Kondo F, Ooka Y, Kato K, Arai M, Suzuki T, Matsumura T, Bekku D, Ito K, Tanaka T, Yokosuka O: Indications for the use of endoscopic mucosal resection for early gastric cancer in Japan: a comparative study with endoscopic submucosal dissection. Endoscopy 2009;41:746-750.

7 Kakushima N, Yahagi N, Fujishiro M, Kodashima S, Nakamura M, Omata M: Efficacy and safety of endoscopic submucosal dissection for tumors of the esophagogastric junction. Endoscopy 2006;38:170174.

8 Yoshinaga S, Gotoda T, Kusano C, Oda I, Nakamura K, Takayanagi R: Clinical impact of endoscopic submucosal dissection for superficial adenocarcinoma located at the esophagogastric junction. Gastrointest Endosc 2008;67:202-209.

-9 Hirasawa K, Kokawa A, Oka H, Yahara S, Sasaki T, Nozawa A, Tanaka K: Superficial adenocarcinoma of the esophagogastric junction: long-term results of endoscopic submucosal dissection. Gastrointest Endosc 2010;72:960-966.

10 Omae M, Fujisaki J, Horiuchi Y, Yoshizawa N, Matsuo Y, Kubota M, Suganuma T, Okada K, Ishiyama A, Hirasawa T, Yamamoto Y, Tsuchida T, Hoshino E, Igarashi M: Safety, efficacy, and long-term outcomes for endoscopic submucosal dissection of early esophagogastric junction cancer. Gastric Cancer 2013;16:147154.

11 Imai K, Kakushima N, Tanaka M, Takizawa K, Matsubayashi H, Hotta K, Yamaguchi Y, Ono H: Validation of the application of the Japanese curative criteria for superficial adenocarcinoma at the esophagogastric junction treated by endoscopic submucosal dissection: a long-term analysis. Surg Endosc 2013;27:24362445.

12 Hoteya S, Matsui A, Iizuka T, Kikuchi D, Yamada A, Yamashita S, Furuhata T, Domon K, Nakamura M, Mitani T, Ogawa O, Kasie M: Comparison of the clinicopathological characteristics and results of endoscopic submucosal dissection for esophagogastric junction and non-junctional cancers. Digestion 2013;87:29-33.

13 Xiang XJ, Deng J, Liu YW, Wan LY, Feng M, Chen J, Xiong JP: MiR-1271 Inhibits Cell Proliferation, Invasion and EMT in Gastric Cancer by Targeting FOXQ1. Cell Physiol Biochem 2015;36:1382-1394.

14 Gotoda T, Yamamoto H, Soetikno RM: Endoscopic submucosal dissection of early gastric cancer. J Gastroenterol 2006;41:929-942.

15 Okada K, Fujisaki J, Yoshida T, Ishikawa H, Suganuma T, Kasuga A, Omae M, Kubota M, Ishiyama A, Hirasawa T, Chino A, Inamori M, Yamamoto Y, Yamamoto N, Tsuchida T, Tamegai Y, Nakajima A, Hoshino E, Igarashi M: Long-term outcomes of endoscopic submucosal dissection for undifferentiated-type early gastric cancer. Endoscopy 2012;44:122-127.

16 Nasu J, Doi T, Endo H, Nishina T, Hirasaki S, Hyodo I: Characteristics of metachronous multiple early gastric cancers after endoscopic mucosal resection. Endoscopy 2005;37:990-993.

17 Bartel DP: MicroRNAs: genomics, biogenesis, mechanism, and function. Cell 2004;116:281-297.

18 Agostini M, Knight RA: miR-34: from bench to bedside. Oncotarget 2014;5:872-881.

19 Bommer GT, Gerin I, Feng Y, Kaczorowski AJ, Kuick R, Love RE, Zhai Y, Giordano TJ, Qin ZS, Moore BB, MacDougald OA, Cho KR, Fearon ER: p53-mediated activation of miRNA34 candidate tumor-suppressor genes. Curr Biol 2007;17:1298-1307.

20 Son MS, Jang MJ, Jeon YJ, Kim WH, Kwon CI, Ko KH, Park PW, Hong SP, Rim KS, Kwon SW, Hwang SG, Kim NK: Promoter polymorphisms of pri-miR-34b/c are associated with hepatocellular carcinoma. Gene 2013;524:156-160. 


\section{Cellular Physiology Cell Physiol Biochem 2017;43:1235-1246 \begin{tabular}{ll|l} 
DOI: 10.1159/000481764 & $\begin{array}{l}\text { O } 2017 \text { The Author(s). Published by S. Karger AG, Basel } \\
\text { www.karger.com/cpb }\end{array}$ \\
\hline and Biochemistry
\end{tabular}}

Yu: Rs4938723 Confers to an Increased Risk of Recurrence after ESD

21 Xu Y, Liu L, Liu J, Zhang Y, Zhu J, Chen J, Liu S, Liu Z, Shi H, Shen H, Hu Z: A potentially functional polymorphism in the promoter region of miR-34b/c is associated with an increased risk for primary hepatocellular carcinoma. Int J Cancer 2011;128:412-417.

-22 Pan XM, Sun RF, Li ZH, Guo XM, Qin HJ, Gao LB: Pri-miR-34b/c rs4938723 polymorphism is associated with a decreased risk of gastric cancer. Genet Test Mol Biomarkers 2015;19:198-202.

23 Wang B, Yang H, Shen L, Wang J, Pu W, Chen Z, Shen X, Fu J, Zhuang Z: Rs56288038 (C/G) in 3'UTR of IRF-1 Regulated by MiR-502-5p Promotes Gastric Cancer Development. Cell Physiol Biochem 2016;40:391-399.

24 Catenacci DV, Henderson L, Xiao SY, Patel P, Yauch RL, Hegde P, Zha J, Pandita A, Peterson A, Salgia R: Durable complete response of metastatic gastric cancer with anti-Met therapy followed by resistance at recurrence. Cancer Discov 2011;1:573-579.

-25 Kawakami H, Okamoto I, Arao T, Okamoto W, Matsumoto K, Taniguchi H, Kuwata K, Yamaguchi H, Nishio K, Nakagawa K, Yamada Y: MET amplification as a potential therapeutic target in gastric cancer. Oncotarget 2013;4:9-17.

-26 Angeles-Angeles A, Candanedo-Gonzalez F, Gamboa-Dominguez A, Larriva-Sahd J: A clinicopathologic variant of intramucosal early gastric cancer with widespread dissemination: report of three cases. J Clin Gastroenterol 1998;27:173-177.

27 Zhou X, Ye F, Yin C, Zhuang Y, Yue G, Zhang G: The Interaction Between MiR-141 and lncRNA-H19 in Regulating Cell Proliferation and Migration in Gastric Cancer. Cell Physiol Biochem 2015;36:1440-1452.

28 Wang D, Fan Z, Liu F, Zuo J: Hsa-miR-21 and Hsa-miR-29 in Tissue as Potential Diagnostic and Prognostic Biomarkers for Gastric Cancer. Cell Physiol Biochem 2015;37:1454-1462.

29 Corso S, Comoglio PM, Giordano S: Cancer therapy: can the challenge be MET? Trends Mol Med 2005;11:284-292.

-30 Trusolino L, Bertotti A, Comoglio PM: MET signalling: principles and functions in development, organ regeneration and cancer. Nat Rev Mol Cell Biol 2010;11:834-848.

-31 Chen Q, Qin R, Fang Y, Li H, Liu Y: A Functional Variant at the miR-214 Binding Site in the Methylenetetrahydrofolatereductase Gene Alters Susceptibility to Gastric Cancer in a Chinese Han Population. Cell Physiol Biochem 2015;36:622-630.

-32 Jeffers M, Rong S, Vande Woude GF: Hepatocyte growth factor/scatter factor-Met signaling in tumorigenicity and invasion/metastasis. J Mol Med (Berl) 1996;74:505-513.

33 Camp RL, Rimm EB, Rimm DL: Met expression is associated with poor outcome in patients with axillary lymph node negative breast carcinoma. Cancer 1999;86:2259-2265.

34 Hida Y, Morita T, Fujita M, Miyasaka Y, Horita S, Fujioka Y, Nagashima K, Katoh H: Clinical significance of hepatocyte growth factor and c-Met expression in extrahepatic biliary tract cancers. Oncol Rep 1999;6:1051-1056.

-35 Li S, Zhang H, Ning T, Wang X, Liu R, Yang H, Han Y, Deng T, Zhou L, Zhang L, Bai M, Ge S, Ying G, Ba Y: MiR520b/e Regulates Proliferation and Migration by Simultaneously Targeting EGFR in Gastric Cancer. Cell Physiol Biochem 2016;40:1303-1315.

-36 Kubo T, Yamamoto H, Lockwood WW, Valencia I, Soh J, Peyton M, Jida M, Otani H, Fujii T, Ouchida M, Takigawa N, Kiura K, Shimizu K, Date H, Minna JD, Varella-Garcia M, Lam WL, Gazdar AF, Toyooka S: MET gene amplification or EGFR mutation activate MET in lung cancers untreated with EGFR tyrosine kinase inhibitors. Int J Cancer 2009;124:1778-1784.

- 37 Bean J, Brennan C, Shih JY, Riely G, Viale A, Wang L, Chitale D, Motoi N, Szoke J, Broderick S, Balak M, Chang WC, Yu CJ, Gazdar A, Pass H, Rusch V, Gerald W, Huang SF, Yang PC, Miller V, Ladanyi M, Yang CH, Pao W: MET amplification occurs with or without T790M mutations in EGFR mutant lung tumors with acquired resistance to gefitinib or erlotinib. Proc Natl Acad Sci U S A 2007;104:20932-20937.

-38 He L, He X, Lim LP, de Stanchina E, Xuan Z, Liang Y, Xue W, Zender L, Magnus J, Ridzon D, Jackson AL, Linsley PS, Chen C, Lowe SW, Cleary MA, Hannon GJ: A microRNA component of the p53 tumour suppressor network. Nature 2007;447:1130-1134.

-39 Corney DC, Flesken-Nikitin A, Godwin AK, Wang W, Nikitin AY: MicroRNA-34b and MicroRNA-34c are targets of p53 and cooperate in control of cell proliferation and adhesion-independent growth. Cancer Res 2007;67:8433-8438.

40 Roy S, Levi E, Majumdar AP, Sarkar FH: Expression of miR-34 is lost in colon cancer which can be reexpressed by a novel agent CDF. J Hematol Oncol 2012;5:58. 


\section{Cellular Physiology Cell Physiol Biochem 2017;43:1235-1246

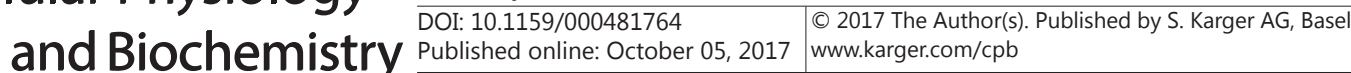

Yu: Rs4938723 Confers to an Increased Risk of Recurrence after ESD

41 Li X, Li H, Zhang R, Liu J: MicroRNA-449a inhibits proliferation and induces apoptosis by directly repressing E2F3 in gastric cancer. Cell Physiol Biochem 2015;35:2033-2042.

42 Iorio MV, Ferracin M, Liu CG, Veronese A, Spizzo R, Sabbioni S, Magri E, Pedriali M, Fabbri M, Campiglio M, Menard S, Palazzo JP, Rosenberg A, Musiani P, Volinia S, Nenci I, Calin GA, Querzoli P, Negrini M, Croce CM: MicroRNA gene expression deregulation in human breast cancer. Cancer Res 2005;65:7065-7070.

43 Duan R, Pak C, Jin P: Single nucleotide polymorphism associated with mature miR-125a alters the processing of pri-miRNA. Hum Mol Genet 2007;16:1124-1131.

-44 Christoffersen NR, Shalgi R, Frankel LB, Leucci E, Lees M, Klausen M, Pilpel Y, Nielsen FC, Oren M, Lund AH: p53-independent upregulation of miR-34a during oncogene-induced senescence represses MYC. Cell Death Differ 2010;17:236-245.

-45 Suzuki R, Yamamoto E, Nojima M, Maruyama R, Yamano HO, Yoshikawa K, Kimura T, Harada T, Ashida M, Niinuma T, Sato A, Nosho K, Yamamoto H, Kai M, Sugai T, Imai K, Suzuki H, Shinomura Y: Aberrant methylation of microRNA-34b/c is a predictive marker of metachronous gastric cancer risk. J Gastroenterol 2014;49:1135-1144.

46 Toyota M, Suzuki H, Sasaki Y, Maruyama R, Imai K, Shinomura Y, Tokino T: Epigenetic silencing of microRNA-34b/c and B-cell translocation gene 4 is associated with CpG island methylation in colorectal cancer. Cancer Res 2008;68:4123-4132.

47 Wang QX, Zhu YQ Zhang H, Xiao J: Altered MiRNA expression in gastric cancer: a systematic review and meta-analysis. Cell Physiol Biochem 2015;35:933-944.

-48 Tsai KW, Wu CW, Hu LY, Li SC, Liao YL, Lai CH, Kao HW, Fang WL, Huang KH, Chan WC, Lin WC: Epigenetic regulation of miR-34b and miR-129 expression in gastric cancer. Int J Cancer 2011;129:2600-2610.

49 Suzuki H, Yamamoto E, Nojima M, Kai M, Yamano HO, Yoshikawa K, Kimura T, Kudo T, Harada E, Sugai T, Takamaru H, Niinuma T, Maruyama R, Yamamoto H, Tokino T, Imai K, Toyota M, Shinomura Y: Methylationassociated silencing of microRNA-34b/c in gastric cancer and its involvement in an epigenetic field defect. Carcinogenesis 2010;31:2066-2073.

50 Hou CG, Luo XY, Li G: Diagnostic and Prognostic Value of Serum MicroRNA-206 in Patients with Gastric Cancer. Cell Physiol Biochem 2016;39:1512-1520.

-51 Zhu P, Zhang J, Zhu J, Shi J, Zhu Q, Gao Y: MiR-429 Induces Gastric Carcinoma Cell Apoptosis Through Bcl-2. Cell Physiol Biochem 2015;37:1572-1580. 